International Journal of Advanced Academic Research | ISSN: 2488-9849

Vol. 7, Issue 5 (May, 2021) | www.ijaar.org

Journal DOI: www.doi.org/10.46654/ij.24889849

Article DOI: www.doi.org/10.46654/ij.24889849.e7573

\title{
ASSESSMENT OF OUTDOOR RADIATION EXPOSURE LEVELS AND HUMAN HEALTH RISK IN A MAJOR SCRAP METAL MARKET IN ABUJA
}

\author{
${ }^{1}$ James, I. U*; ${ }^{2}$ Onuh E; ${ }^{3}$ Moses, I. F; ${ }^{4}$ Ukeme U. E and ${ }^{5}$ Vandi, J. N

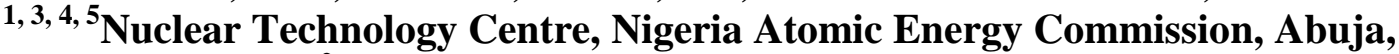 \\ ${ }^{2}$ Department of Physics, Ahmadu Bello University, Zaria \\ *Corresponding Author Email: jamesfam2002@yahoo.com
}

\begin{abstract}
Background: Scrap metal can contain sources of radiation with the associated environmental and health risks. Radioactive substances can become associated with scrap metal in various ways and if not discovered they can be incorporated into steel and non-ferrous metals through the melting process. This can cause health hazards to workers and to the public as well as environmental concerns

Objectives: this study aimed at assessing the outdoor radiation exposure levels and human health risk in a major scrap metal market in Abuja, FCT.

Method: An in-situ measurement approach was adopted using a factory calibrated Radiagem2000 Universal Survey Meter and a handheld Global Positioning System (Garmin GPS 76S) equipment. The monitor was suspended in air at one meter above the ground level. Readings were obtained between the hours of 1200 and 1600 hours since the exposure rate meter has a maximum response to environmental radiation within these hours.

Results: The results showed that the average values for the outdoor exposure dose rate for the three location ranges from $0.173 \pm 0.042 \mu \mathrm{Sv} / \mathrm{h}$ to $0.177 \pm 0.046 \mu \mathrm{Sv} / \mathrm{h}$ with a mean of $0.176 \pm 0.045$ $\mu \mathrm{Sv} / \mathrm{h}$. These values, though, slightly higher than the standard background radiation of 0.133 $\mu \mathrm{Sv} / \mathrm{h}$,are below the ICRP maximum permissible limit of $0.57 \mu \mathrm{Sv} / \mathrm{h}$. The results also show that the AEDE values are lower than the ICRP recommended limits of $1.0 \mathrm{mSv} / \mathrm{y}$ for the public and $20 \mathrm{mSv} / \mathrm{y}$ for occupationally exposed workers. The ELCR ranges from $0.5926 \times 10^{-3}$ to $0.6049 x$ $10^{-3}$ with a mean of $0.6008 \times 10^{-3}$ which is 2.1 times higher than the world's average. The dosage to organs received shows that the testes have the highest dose while the liver has the lowest dose. The result of the dose to the organs showed that all the values are below the international tolerable limits.

Conclusion: Generally, The radiological assessment shows that the study area does not constitute any immediate radiological health effect on the workers and the general public due to radiation exposure rate.
\end{abstract}

Keywords: Scrap metals, radioactive substance, in-situ, health risk 


\section{INTRODUCTION}

The current study is hinged on the recommendation of the International Commission on Radiological Protection, ICRP 103 (2007). This recommendation states that "The likelihood of incurring exposures, the number of people exposed, and the magnitude of their individual doses should be kept As Low As Reasonably Achievable (ALARA), taking into account economic and societal factors. Also the International Basic Safety Standards (BSS) states that "Radiation sources and installations should be provided with the best available protection and safety measures under the prevailing circumstances, so that the magnitudes and likelihood of exposures and the numbers of individuals exposed be as low as reasonably achievable, economic and social factors being taken into account, and the doses they deliver and the risk they entail be constrained" (IAEA, Safety Series 115. 1996).

Radioactive sources are used in a wide variety of applications in medicine, industry and research for societal benefits. These applications involve use of both sealed and unsealed sources. Radioactivity in such sources varies from a few $\mathrm{kBq}(\mu \mathrm{Ci})$ to hundreds of $\mathrm{TBq}$ (thousands of curies) ICCMRM [2009). The national regulatory bodies in each country control the use of such radioactive sources. A lost source accident occurs when a radioactive object is lost or stolen. Such objects may appear in the scrap metal industry if people mistake them for harmless bits of metal (UNECE, 2006). It has been observed that in spite of regulatory control there are incidents of theft, loss or abandoned radioactive sources worldwide. These lost or stolen sources sometimes get into the metal scrap used in metal recycling industry and ultimately end up as a consumer product with radioactive contamination. Incidents related to the export of contaminated steel products such as steel handle doors, manhole covers, steel tension bars, copper coated steel grounding rods, steel wires, nails and metal straps used for packaging, metal fittings used in hand bags etc. have been reported (ICCMRM 2009).

Scrap metal can contain sources of radiation with the associated environmental and health risks. Higher levels of radiation are possible and may stem from losses, accidents or the inadvertent disposal of radioactive material (Lenka and Peter, 2010). Radioactive metal scrap may also come from military applications (such as depleted uranium), industrial and research irradiator activities, teletherapy, industrial radiography, discarded medical equipment, gauges, logging, and pipes from the potash industry, building or storage material from nuclear power plants (particularly nickel scrap) or trace amounts found elsewhere, such as Americium (Am-241), found in smoke detectors(OSHA, 2008). Exposure to radiation from radioactive sources mixed with metal scrap can be significant, even injurious.

The detection of, and the response to, radioactive scrap metal is complicated by the fact that radioactive substances are ubiquitous in nature and, specifically, that metal ores contain radioactive elements. When low levels of radionuclides are detected in scrap metal it is sometimes difficult to determine whether the radionuclides are naturally occurring or have been added through human activities. The frequency at which radioactive scrap metal is detected may be expected to continue to rise with the ever-increasing use of scrap to produce processed materials, the wider application of radiation monitoring procedures and the ever-increasing effectiveness of radiation detection equipment (UNECE, 2006). 
Several measures have been aimed at detecting radioactive scrap metal at the earliest possible stage in the recycling chain, but its detection is not an easy task. Even with the most sensitive and sophisticated equipment, radioactive scrap metal may be undetected and be introduced into the recycling process. Radioactive scrap metal is an issue in both developed and developing countries, but the developing countries are generally less well equipped and have a lesser capacity for dealing with the problem. This research aims at assessing the outdoor radiation exposure level and human health risk in a major scrap metal market in Abuja, Nigeria.

\section{MATERIALS AND METHODS}

\subsection{Study Area}

Abuja, Nigeria's capital city is located in the middle of the country. The Federal Capital Territory has a land area of 8,000 square kilometers, which is two and half times the size of Lagos, the former capital of Nigeria. The FCT is bounded on the north by Kaduna State, on the west by Niger State, on the east and south-east by Nasarawa State, and on the south-west by Kogi State. Abuja lies at latitude $9^{\circ} 4^{\prime} 0^{\prime \prime} \mathrm{N}$ and Longitude $7^{\circ} 29^{\prime} 0^{\prime \prime} \mathrm{E}$. The FCT is made up of six (6) area councils-Abaji, Abuja Municipal, Bwari, Gwagwalada, Kuje and Kwali.

The area under investigation is Dei Dei International Market which houses the International Building Materials market located in Abuja Municipal area council. The International Building Materials market is a very large market by all standards. A lot of business activities are carried out in the market. The scrap metal market is a section of the International Building Materials market. The scrap metal market is divided into three (3) sections; the Automobile/Heavy Duty Equipment scrap (Site A), Building Materials scrap (Site B) and Medical/Industrial scraps (Site C).

\subsection{Instrumentation}

An in-situ approach of background radiation measurement was adopted and preferred to enable samples maintain their original environmental characteristics. A portable Dose rate meter, Radiagem 2000 and a Geographical Positioning System (GPS) Garmin 76S were used for the measurement. The Radiagem 2000 portable Dose rate Meter is an excellent, portable multipurpose radiation meter for a wide range of applications. It is a survey meter that includes an energy-compensated Geiger-Muller tube that measures the dose equivalent. It is especially designed for situations where accurate measurements at low dose rate levels are of importance. The assessment was achieved using a factory calibrated Radiagem 2000.Portable survey meter (SN: 4423, Canberra, France). The monitor was suspended in air at one meter above the ground level. Readings were obtained between the hours of 1200 and 1600 hours since the exposure rate meter has a maximum response to environmental radiation within these hours as recommended (NCRP, 1976; Oyeyinka et al, 2012). Three readings were taken at each outdoor location and the mean values were recorded.

\subsection{Radiation Health Risk Assessment}

Different known radiation health hazard indices analysis is been use in radiation studies to arrive at a better and safer conclusion on the health status of a radiated or irradiated person and 
Journal DOI: www.doi.org/10.46654/ij.24889849

environment (Avwiri et al., 2012). The measured results (raw data) obtained from the study area were analyzed and compared with regulatory standards. For effective computation of the experimental data from Exposure rate (in $\mu \mathrm{Sv} / \mathrm{hr}$ ) to Absorbed Dose (in $\mathrm{nGy} / \mathrm{hr}$ ), to calculate the Annual Effective Dose Equivalent (in $\mathrm{mSv} / \mathrm{yr}$ ), Excess Lifetime Cancer Risk (in mSv/y), Effective dose rate to the organ (Dorgan) (in $\mathrm{mSv} / \mathrm{y}$ ) the following conversion formula was used;

To Convert from Exposure rate (in $\mu \mathrm{Sv} / \mathrm{hr}$ ) to Absorbed Dose (in $\mathrm{nGy} / \mathrm{hr}$ )

$1 \mu \mathrm{Sv} / \mathrm{hr}=10^{-3} \mathrm{nGy} / \mathrm{hr}$

To Calculate the Annual Effective Dose Equivalent (in $\mathrm{mSv} / \mathrm{y}$ )

$\mathrm{E}(\mathrm{mSv} / \mathrm{y})=\mathrm{D}(\mathrm{nGy} / \mathrm{hr}) \times \mathrm{T} \times \mathrm{OF} \times \mathrm{CC} \times 10^{-6}$

Where,

$\mathrm{E}=$ Annual Effective Dose Equivalent $(\mathrm{mSv} / \mathrm{y})$

$\mathrm{D}=$ Absorbed Dose $(\mathrm{nGy} / \mathrm{hr})$

$\mathrm{T}=$ Working Hours per Year $=8760 \mathrm{~h} / \mathrm{y}$

$\mathrm{OF}=$ Occupancy Factor $=0.2($ Outdoor $)$

$\mathrm{CC}=$ Conversion Coefficient $=0.7 \mathrm{~Sv} / \mathrm{Gy}$

To Calculate the Excess Lifetime Cancer Risk (in mSv/y)

$\mathrm{ELCR}=\mathrm{AEDE} \times \mathrm{LE} \times \mathrm{RF}$

Where,

$\mathrm{AEDE}=$ Annual Effective Dose Equivalent

LE $=$ Life Expectancy $=55.8$ years (www.worldometer.info/Nigeria)

$\mathrm{RF}=$ Risk Factor $=0.05 \mathrm{~Sv}^{-1}$. For stochastic effects ICRP 60 recommend $\mathrm{RF}=0.05$ for the public (Taskin et al., 2009).

To calculate the Effective dose rate to the organ $\left(D_{\text {organ }}\right)$

$\mathrm{D}_{\text {organ }}(\mathrm{mSv} / \mathrm{y})=\mathrm{AEDE} \times \mathrm{F}$

Where $\mathrm{F}$ is the conversion factor of organ dose from air dose. 


\section{RESULTS AND DISCUSSION}

Exposure Dose Rate: The outdoor data obtained from the in-situ measurement for the three locations within the study area were processed for mean value by adding up all the raw data obtained for each location and divided by the number of data taken to get the mean value for the location. The result is as shown in Tables 1-3. A summary of the Outdoor Exposure Dose Rate and calculated hazard Indices for the three locations (Table 4) shows that the outdoor exposure dose rate ranges from $0.173 \pm 0.042 \mu \mathrm{Sv} / \mathrm{h}$ to $0.177 \pm 0.046 \mu \mathrm{Sv} / \mathrm{h}$ with a mean of $0.176 \pm 0.045$ $\mu \mathrm{Sv} / \mathrm{h}$. These values, though, slightly higher than the standard background radiation of 0.133 $\mu \mathrm{Sv} / \mathrm{h}$, but are below the ICRP maximum permissible limit of $0.57 \mu \mathrm{Sv} / \mathrm{h}$.

Annual Effective Dose Equivalent (AEDE): Radiation absorbed dose is a measure of the amount of energy absorbed per unit mass. It quantifies the radiation energy that might be absorbed by a potentially exposed individual as a result of a specific exposure. For whole body exposure, the quantity effective dose equivalent is used to measure the whole body absorbed dose. The annual effective dose equivalent (AEDE) is used in radiation assessment and protection to quantify the whole body absorbed dose per year. The AEDE for the three locations is shown in (Tables 1-3). A summary of the AEDE (Table 4) shows that the outdoor AEDE ranges from $0.2124 \pm 0.0512 \mathrm{mSv} / \mathrm{y}$ to $0.2168 \pm 0.0572 \mathrm{mSv} / \mathrm{y}$ with a mean of $0.2153 \pm 0.0552$ $\mathrm{mSv} / \mathrm{y}$. These values are lower than the ICRP recommended limits of $1.0 \mathrm{mSv} / \mathrm{y}$ for the public and $20 \mathrm{mSv} / \mathrm{y}$ for occupationally exposed workers. This indicates that the studied areas are in good agreement with permissible limit and do not constitute any immediate radiological health effect on the workers and the general public due to background ionizing radiation (BIR) exposure. However, periodic assessment of activity concentration of natural radionuclides and BIR levels in the study area should be carried out in order to ensure that exposure to radiation within the areas is kept to as low as reasonably achievable.

Excess Lifetime Cancer Risk (ELCR): The excess lifetime cancer risk is used in radiation protection assessment to predict the probability of an individual developing cancer over his lifetime due to low radiation dose exposure, if it will occur at all. The ELCR for the three locations is shown in shown in (Tables 1-3). A summary of the ELCR (Table 4) showsthat the Outdoor ELCR ranges from $0.5926 \times 10^{-3}$ to $0.6049 \times 10^{-3}$ with a mean of $0.6008 \times 10^{-3}$ which is 2.1 times higher than the world's average of $0.29 \times 10^{-3}$ (Qureshi et al., 2014). These values for excess lifetime cancer risk indicate that the probability of cancer development by workers and residents who wish to spend all their life time in the area is very low. The ELCR values reported in this study are lower than those reported for industrial areas of Warri and Effurun, Delta State, Nigeria (Agbalagba. 2017), and also lower than those for the salt lake environment of Okposi Okwu and Uburu of Ebonyi State, Nigeria (Avwiri et al., 2016). It is slightly higher than the values from some scrap metal dumpsites in Nasarawa state (Kerinja et al.,2020), Emene Industrial Layout, Enugu (Ugbede and Benson, 2018), Unity park, Uyo, Akwa Ibom state, Nigeria (Etuk et al., 2017) and river sediments from Northern Pakistan (Qureshi et al, 2014).

Effective dose rate ( $\left.D_{\text {organ }}\right)$ to different body organs and tissues: The effective dose to organs $\left(D_{\text {organ }}\right)$ estimates the amount of radiation dose intake to various body organs and tissues. The result of the effective dose rate delivered to the different organs in the three locations is presented in Figure 1, with the F values for Lungs, Ovaries, Bone marrow, Testes, Kidneys, 
Liver and Whole body given as $0.64,0.58,0.69,0.82,0.62,0.46$ and 0.68 respectively, obtained from ICRP [1996]. The estimated average $\mathrm{D}_{\text {organ }}$ values for the lungs, ovaries, bone marrow, testes, kidney, liver and whole body due to radiation exposure and inhalation in the three location (sites A-C) are 0.026, 0.024,0.028, 0.033, 0.025, 0.019, 0.028 respectively. These results are all below the international tolerable limits of $1.0 \mathrm{mSv} / \mathrm{y}$ (Agbalagba, 2017, Ugbede and Benson, 2018) which further shows that the radiation levels do not constitute any immediate health effect on workers and residents of the study area. From the results, it is concluded that the testes and liver have highest and lowest sensitivity to radiation. The relatively higher dose to the testes and low dose intake to the liver is justifiable from food nutrient absorption rate (Zaid et al., 2010). This shows that the impact of exposure to background ionizing radiation levels in the study area contributes insignificantly to the radiation dose to these organs of the adult. Similar conclusion has also been made by Agbalagba (2017), and Ugbede and Benson, (2018).

Table 1: Measured Outdoor Exposure Dose Rate and Calculated Hazard Indices in site A

\begin{tabular}{|c|c|c|c|c|c|c|}
\hline $\begin{array}{c}\text { Sampling } \\
\text { point } \\
\text { code }\end{array}$ & Latitude & Longitude & $\begin{array}{c}\text { Exposure } \\
\text { Rate } \\
\text { (uSv/hr) }\end{array}$ & $\begin{array}{l}\text { Absorbed } \\
\text { Dose } \\
\text { (nG/hr) }\end{array}$ & $\begin{array}{c}\text { AEDE } \\
\text { (Outdoor) } \\
(\mathbf{m S v} / \mathbf{y})\end{array}$ & $\begin{array}{c}\text { ELCR } \\
\text { (Outdoor) } \\
\mathbf{x} 10^{-3}\end{array}$ \\
\hline $\mathrm{A} 1$ & $09^{\circ} 06.411^{\prime} \mathrm{N}$ & $007^{\circ} 16.195^{\prime} \mathrm{E}$ & 0.100 & 100 & 0.1226 & 0.3422 \\
\hline $\mathrm{A} 2$ & $09^{\circ} 06.415^{\prime} \mathrm{N}$ & $007^{\circ} 16.192^{\prime} \mathrm{E}$ & 0.140 & 140 & 0.1717 & 0.4790 \\
\hline A3 & $09^{\circ} 06.420^{\prime} \mathrm{N}$ & $007^{\circ} 16.192 \mathrm{E}$ & 0.140 & 140 & 0.1717 & 0.4790 \\
\hline A4 & $09^{\circ} 06.413^{\prime} \mathrm{N}$ & $007^{\circ} 16.189^{\prime} \mathrm{E}$ & 0.100 & 100 & 0.1226 & 0.3422 \\
\hline A5 & $09^{\circ} 06.408^{\prime} \mathrm{N}$ & $007^{\circ} 16.187^{\prime} \mathrm{E}$ & 0.100 & 100 & 0.1226 & 0.3422 \\
\hline A6 & $09^{\circ} 06.409^{\prime} \mathrm{N}$ & $007^{\circ} 16.182^{\prime} \mathrm{E}$ & 0.160 & 160 & 0.1962 & 0.5475 \\
\hline A7 & $09^{\circ} 06.413^{\prime} \mathrm{N}$ & $007^{\circ} 16.183^{\prime} \mathrm{E}$ & 0.160 & 160 & 0.1962 & 0.5475 \\
\hline A8 & $09^{\circ} 06.419^{\prime} \mathrm{N}$ & $007^{\circ} 16.181^{\prime} \mathrm{E}$ & 0.130 & 130 & 0.1594 & 0.4448 \\
\hline A9 & $09^{\circ} 06.408^{\prime} \mathrm{N}$ & $007^{\circ} 16.213^{\prime} \mathrm{E}$ & 0.180 & 180 & 0.2208 & 0.6159 \\
\hline A10 & $09^{\circ} 06.396^{\prime} \mathrm{N}$ & $007^{\circ} 16.215^{\prime} \mathrm{E}$ & 0.240 & 240 & 0.2943 & 0.8212 \\
\hline A11 & $09^{\circ} 06.401^{\prime} \mathrm{N}$ & $007^{\circ} 16.210^{\prime} \mathrm{E}$ & 0.140 & 140 & 0.1717 & 0.4790 \\
\hline A12 & $09^{\circ} 06.392 \mathrm{~N}$ & $007^{\circ} 16.209^{\prime} \mathrm{E}$ & 0.160 & 160 & 0.1962 & 0.5475 \\
\hline A13 & $09^{\circ} 06.390^{\prime} \mathrm{N}$ & $007^{\circ} 16.213^{\prime} \mathrm{E}$ & 0.110 & 110 & 0.1349 & 0.3764 \\
\hline A14 & $09^{\circ} 06.385^{\prime} \mathrm{N}$ & $007^{\circ} 16.213^{\prime} \mathrm{E}$ & 0.100 & 100 & 0.1226 & 0.3422 \\
\hline A15 & $09^{\circ} 06.382^{\prime} \mathrm{N}$ & $007^{\circ} 16.210^{\prime} \mathrm{E}$ & 0.140 & 140 & 0.1717 & 0.4790 \\
\hline A16 & $09^{\circ} 06.378^{\prime} \mathrm{N}$ & $007^{\circ} 16.213^{\prime} \mathrm{E}$ & 0.110 & 110 & 0.1349 & 0.3764 \\
\hline A17 & $09^{\circ} 06.374^{\prime} \mathrm{N}$ & $007^{\circ} 16.208^{\prime} \mathrm{E}$ & 0.100 & 100 & 0.1226 & 0.3422 \\
\hline A18 & $09^{\circ} 06.373^{\prime} \mathrm{N}$ & $007^{\circ} 16.214 \mathrm{E}$ & 0.100 & 100 & 0.1226 & 0.3422 \\
\hline A19 & $09^{\circ} 06.365^{\prime} \mathrm{N}$ & $007^{\circ} 16.214^{\prime} \mathrm{E}$ & 0.170 & 170 & 0.2085 & 0.5817 \\
\hline A20 & $09^{\circ} 06.362^{\prime} \mathrm{N}$ & $007^{\circ} 16.215^{\prime} \mathrm{E}$ & 0.160 & 160 & 0.1962 & 0.5475 \\
\hline A21 & $09^{\circ} 06.356^{\prime} \mathrm{N}$ & $007^{\circ} 16.210^{\prime} \mathrm{E}$ & 0.240 & 240 & 0.2943 & 0.8212 \\
\hline A22 & $09^{\circ} 06.353 \mathrm{~N}$ & $007^{\circ} 16.213^{\prime} \mathrm{E}$ & 0.160 & 160 & 0.1962 & 0.5475 \\
\hline A23 & $09^{\circ} 06.351^{\prime} \mathrm{N}$ & $007^{\circ} 16.208^{\prime} \mathrm{E}$ & 0.190 & 190 & 0.2330 & 0.6501 \\
\hline A24 & $09^{\circ} 06.250^{\prime} \mathrm{N}$ & $007^{\circ} 16.205^{\prime} \mathrm{E}$ & 0.140 & 140 & 0.1717 & 0.4790 \\
\hline $\mathrm{A} 25$ & $09^{\circ} 06.339^{\prime} \mathrm{N}$ & $007^{\circ} 16.206^{\prime} \mathrm{E}$ & 0.180 & 180 & 0.2208 & 0.6159 \\
\hline Mean \pm SD & & & $0.146 \pm 0.04$ & $146 \pm 40.4$ & $0.1791 \pm 0.0495$ & $0.4996 \pm 0.1382$ \\
\hline
\end{tabular}


International Journal of Advanced Academic Research | ISSN: 2488-9849

Vol. 7, Issue 5 (May, 2021) | www.ijaar.org

Journal DOI: www.doi.org/10.46654/ij.24889849

Article DOI: $\underline{\text { www.doi.org/10.46654/ij.24889849.e7573 }}$

Table 2: Measured Outdoor Exposure Dose Rate and Calculated Hazard Indices in site B

\begin{tabular}{|c|c|c|c|c|c|c|}
\hline $\begin{array}{l}\text { Samplin } \\
\text { g point } \\
\text { code }\end{array}$ & Latitude & Longitude & $\begin{array}{c}\text { Exposure } \\
\text { Rate } \\
(\text { uSv/hr) }\end{array}$ & $\begin{array}{c}\text { Absorbed } \\
\text { Dose } \\
(\mathbf{n G} / \mathbf{h r})\end{array}$ & $\begin{array}{c}\text { AEDE } \\
\text { (Outdoor) } \\
(\mathbf{m S v} / \mathbf{y})\end{array}$ & $\begin{array}{c}\text { ELCR } \\
\text { (Outdoor) } \\
\mathbf{x} 10^{-3}\end{array}$ \\
\hline B1 & $09^{\circ} 06.339^{\prime} \mathrm{N}$ & $\begin{array}{c}007^{\circ} 16.214^{\prime} \\
\mathrm{E}\end{array}$ & 0.200 & 200 & 0.2453 & 0.6843 \\
\hline B2 & $09^{\circ} 06.338^{\prime} \mathrm{N}$ & $\begin{array}{c}007^{\circ} 16.218^{\prime} \\
\mathrm{E}\end{array}$ & 0.220 & 220 & 0.2698 & 0.7528 \\
\hline B3 & $09^{\circ} 06.337^{\prime} \mathrm{N}$ & $\begin{array}{cl}007^{0} & 16.225^{\prime} \\
& E\end{array}$ & 0.140 & 140 & 0.1717 & 0.4790 \\
\hline B4 & $09^{\circ} 06.334^{\prime} \mathrm{N}$ & $\begin{array}{cl}007^{\circ} & 16.232^{\prime} \\
& \mathrm{E}\end{array}$ & 0.200 & 200 & 0.2453 & 0.6843 \\
\hline B5 & $09^{\circ} 06.325^{\prime} \mathrm{N}$ & $\begin{array}{c}007^{\circ} 16.230^{\prime} \\
\text { E } \\
\end{array}$ & 0.180 & 180 & 0.2208 & 0.6159 \\
\hline B6 & $09^{\circ} 06.324 ' \mathrm{~N}$ & $\begin{array}{cl}007^{\circ} 16.230^{\prime} \\
\text { E }\end{array}$ & 0.210 & 210 & 0.2575 & 0.7185 \\
\hline B7 & $09^{\circ} 06.303^{\prime} \mathrm{N}$ & $\begin{array}{cl}007^{\circ} & 16.228^{\prime} \\
& \mathrm{E} \\
\end{array}$ & 0.180 & 180 & 0.2208 & 0.6159 \\
\hline B8 & $09^{\circ} 06.291^{\prime} \mathrm{N}$ & $\begin{array}{cl}007^{\circ} & 16.227^{\prime} \\
& E\end{array}$ & 0.140 & 140 & 0.1717 & 0.4790 \\
\hline B9 & $09^{\circ} \quad 06.284^{\prime} \mathrm{N}$ & $\begin{array}{c}007^{\circ} 16.221^{\prime} \\
\mathrm{E}\end{array}$ & 0.140 & 140 & 0.1717 & 0.4790 \\
\hline B10 & $09^{\circ} 06.271^{\prime} \mathrm{N}$ & $\begin{array}{c}007^{\circ} \\
16.227^{\prime} \\
\mathrm{E}\end{array}$ & 0.180 & 180 & 0.2208 & 0.6159 \\
\hline B11 & $09^{\circ} 06.270^{\prime} \mathrm{N}$ & $\begin{array}{cl}007^{\circ} & 16.230^{\prime} \\
& \mathrm{E}\end{array}$ & 0.200 & 200 & 0.2453 & 0.6843 \\
\hline B12 & $09^{\circ} 06.254^{\prime} \mathrm{N}$ & $\begin{array}{c}007^{\circ} 16.227^{\prime} \\
\mathrm{E}\end{array}$ & 0.240 & 240 & 0.2943 & 0.8212 \\
\hline B13 & $09^{\circ} 06.252^{\prime} \mathrm{N}$ & $\begin{array}{ll}007^{\circ} & 16.230^{\prime} \\
& \mathrm{E}\end{array}$ & 0.220 & 220 & 0.2698 & 0.7528 \\
\hline B14 & $09^{\circ} 06.241^{\prime} \mathrm{N}$ & $\begin{array}{cl}007^{\circ} 16.230^{\prime} \\
\\
\mathrm{E}\end{array}$ & 0.180 & 180 & 0.2208 & 0.6159 \\
\hline B15 & $09^{\circ} 06.240^{\prime} \mathrm{N}$ & $\begin{array}{cl}007^{\circ} & 16.226^{\prime} \\
& \mathrm{E} \\
\end{array}$ & 0.180 & 180 & 0.2208 & 0.6159 \\
\hline B16 & $09^{\circ} 06.233^{\prime} \mathrm{N}$ & $\begin{array}{cl}007^{\circ} & 16.232^{\prime} \\
& \mathrm{E}\end{array}$ & 0.160 & 160 & 0.1962 & 0.5475 \\
\hline B17 & $09^{\circ} 06.225^{\prime} \mathrm{N}$ & $\begin{array}{cl}007^{\circ} & 16.228^{\prime} \\
& \mathrm{E} \\
\end{array}$ & 0.200 & 200 & 0.2453 & 0.6843 \\
\hline B18 & $09^{\circ} 06.215^{\prime} \mathrm{N}$ & $\begin{array}{cl}007^{\circ} & 16.225^{\prime} \\
& E\end{array}$ & 0.100 & 100 & 0.1226 & 0.3422 \\
\hline B19 & $09^{\circ} 06.205^{\prime} \mathrm{N}$ & $\begin{array}{cl}007^{\circ} & 16.227^{\prime} \\
& \mathrm{E} \\
\end{array}$ & 0.200 & 200 & 0.2453 & 0.6843 \\
\hline B20 & $09^{\circ} 06.194^{\prime} \mathrm{N}$ & $\begin{array}{c}007^{\circ} 16.227^{\prime} \\
\text { E }\end{array}$ & 0.220 & 220 & 0.2698 & 0.7528 \\
\hline B21 & $09^{\circ} 06.198^{\prime} \mathrm{N}$ & $\begin{array}{cl}007^{\circ} & 16.214^{\prime} \\
& E\end{array}$ & 0.220 & 220 & 0.2698 & 0.7528 \\
\hline B22 & $09^{\circ} 06.201^{\prime} \mathrm{N}$ & $\begin{array}{cl}007^{\circ} 16.206^{\prime} \\
\mathrm{E}\end{array}$ & 0.090 & 90 & 0.1104 & 0.3079 \\
\hline B23 & $09^{\circ} 06.215^{\prime} \mathrm{N}$ & $\begin{array}{c}007^{\circ} 16.214^{\prime} \\
\text { E }\end{array}$ & 0.080 & 80 & 0.0981 & 0.2737 \\
\hline B24 & $09^{\circ} 06.215^{\prime} \mathrm{N}$ & $\begin{array}{cl}007^{\circ} 16.200^{\prime} \\
\mathrm{E}\end{array}$ & 0.100 & 100 & 0.1226 & 0.3422 \\
\hline $\mathrm{B} 25$ & $09^{\circ} 06.213^{\prime} \mathrm{N}$ & $\begin{array}{cl}007^{\circ} & 16.199^{\prime} \\
& \mathrm{E}\end{array}$ & 0.240 & 240 & 0.2943 & 0.8212 \\
\hline $\begin{array}{l}\text { Mean } \pm \\
\text { SD }\end{array}$ & & & $0.177 \pm 0.046$ & $176.8 \pm 46.7$ & $0.2168 \pm 0.0572$ & $0.6049 \pm 0.1597$ \\
\hline
\end{tabular}


International Journal of Advanced Academic Research | ISSN: 2488-9849

Vol. 7, Issue 5 (May, 2021) | www.ijaar.org

Journal DOI: www.doi.org/10.46654/ij.24889849

Article DOI: www.doi.org/10.46654/iij.24889849.e7573

Table 3: Measured Outdoor Exposure Dose Rate and Calculated Hazard Indices in site C

\begin{tabular}{|c|c|c|c|c|c|c|}
\hline $\begin{array}{l}\text { Sampling } \\
\text { point } \\
\text { code }\end{array}$ & Latitude & Longitude & $\begin{array}{c}\text { Exposure } \\
\text { Rate } \\
\text { (uSv/hr) }\end{array}$ & $\begin{array}{c}\text { Absorbed } \\
\text { Dose } \\
\text { (nG/hr) }\end{array}$ & $\begin{array}{c}\text { AEDE } \\
\text { (Outdoor) } \\
(\mathbf{m S v} / \mathbf{y})\end{array}$ & $\begin{array}{c}\text { ELCR } \\
\text { (Outdoor) } \\
\mathbf{x} 10^{-3}\end{array}$ \\
\hline $\mathrm{C} 1$ & $09^{\circ} 06.224^{\prime} \mathrm{N}$ & $007^{\circ} 16.179^{\prime} \mathrm{E}$ & 0.170 & 170 & 0.2085 & 0.5817 \\
\hline $\mathrm{C} 2$ & $09^{\circ} 06.226^{\prime} \mathrm{N}$ & $007^{\circ} 16.217^{\prime} \mathrm{E}$ & 0.140 & 140 & 0.1717 & 0.4790 \\
\hline C3 & $09^{\circ} 06.236^{\prime} \mathrm{N}$ & $007^{\circ} \quad 16.242 \mathrm{E}$ & 0.140 & 140 & 0.1717 & 0.4790 \\
\hline $\mathrm{C} 4$ & $09^{\circ} 06.242^{\prime} \mathrm{N}$ & $007^{\circ} 16.212^{\prime} \mathrm{E}$ & 0.160 & 160 & 0.1962 & 0.5475 \\
\hline C5 & $09^{\circ} 06.245^{\prime} \mathrm{N}$ & $007^{\circ} \quad 16.207^{\prime} \mathrm{E}$ & 0.140 & 140 & 0.1717 & 0.4790 \\
\hline C6 & $09^{\circ} 06.256^{\prime} \mathrm{N}$ & $007^{\circ} 16.213^{\prime} \mathrm{E}$ & 0.200 & 200 & 0.2453 & 0.6843 \\
\hline C7 & $09^{\circ} 06.257^{\prime} \mathrm{N}$ & $007^{\circ} \quad 16.210^{\prime} \mathrm{E}$ & 0.180 & 180 & 0.2208 & 0.6159 \\
\hline $\mathrm{C} 8$ & $09^{\circ} 06.265^{\prime} \mathrm{N}$ & $007^{\circ} 16.214^{\prime} \mathrm{E}$ & 0.140 & 140 & 0.1717 & 0.4790 \\
\hline C9 & $09^{\circ} 06.270^{\prime} \mathrm{N}$ & $007^{\circ} 16.209^{\prime} \mathrm{E}$ & 0.220 & 220 & 0.2698 & 0.7528 \\
\hline $\mathrm{C} 10$ & $09^{\circ} 06.276^{\prime} \mathrm{N}$ & $007^{\circ} 16.208^{\prime} \mathrm{E}$ & 0.180 & 180 & 0.2208 & 0.6159 \\
\hline $\mathrm{C} 11$ & $09^{\circ} 06.282^{\prime} \mathrm{N}$ & $007^{\circ} 16.210^{\prime} \mathrm{E}$ & 0.260 & 260 & 0.3189 & 0.8896 \\
\hline $\mathrm{C} 12$ & $09^{\circ} 06.280^{\prime} \mathrm{N}$ & $007^{\circ} \quad 16.210^{\prime} \mathrm{E}$ & 0.140 & 140 & 0.1717 & 0.4790 \\
\hline $\mathrm{C} 13$ & $09^{\circ} 06.280^{\prime} \mathrm{N}$ & $007^{\circ} 16.212^{\prime} \mathrm{E}$ & 0.130 & 130 & 0.1594 & 0.4448 \\
\hline $\mathrm{C} 14$ & $09^{\circ} 06.286^{\prime} \mathrm{N}$ & $007^{\circ} 16.209^{\prime} \mathrm{E}$ & 0.130 & 130 & 0.1594 & 0.4448 \\
\hline $\mathrm{C} 15$ & $09^{\circ} 06.283^{\prime} \mathrm{N}$ & $007^{0} 16.201^{\prime} \mathrm{E}$ & 0.180 & 180 & 0.2208 & 0.6159 \\
\hline $\mathrm{C} 16$ & $09^{\circ} 06.346 \mathrm{~N}$ & $007^{\circ} 16.209^{\prime} \mathrm{E}$ & 0.180 & 180 & 0.2208 & 0.6159 \\
\hline $\mathrm{C} 17$ & $09^{\circ} 06.352^{\prime} \mathrm{N}$ & $007^{\circ} 16.214^{\prime} \mathrm{E}$ & 0.100 & 100 & 0.1226 & 0.3422 \\
\hline $\mathrm{C} 18$ & $09^{\circ} 06.357^{\prime} \mathrm{N}$ & $007^{\circ} \quad 16.209^{\prime} \mathrm{E}$ & 0.120 & 120 & 0.1472 & 0.4106 \\
\hline C19 & $09^{\circ} 06.311^{\prime} \mathrm{N}$ & $007^{\circ} \quad 16.213^{\prime} \mathrm{E}$ & 0.180 & 180 & 0.2208 & 0.6159 \\
\hline $\mathrm{C} 20$ & $09^{\circ} 06.363^{\prime} \mathrm{N}$ & $007^{\circ} 16.207^{\prime} \mathrm{E}$ & 0.260 & 260 & 0.3189 & 0.8896 \\
\hline $\mathrm{C} 21$ & $09^{\circ} 06.396^{\prime} \mathrm{N}$ & $007^{\circ} 16.212^{\prime} \mathrm{E}$ & 0.220 & 220 & 0.2698 & 0.7528 \\
\hline $\mathrm{C} 22$ & $09^{\circ} 06.373^{\prime} \mathrm{N}$ & $007^{\circ} \quad 16.209^{\prime} \mathrm{E}$ & 0.160 & 160 & 0.1962 & 0.5475 \\
\hline $\mathrm{C} 23$ & $09^{\circ} 06.396^{\prime} \mathrm{N}$ & $007^{\circ} \quad 16.200^{\prime} \mathrm{E}$ & 0.180 & 180 & 0.2208 & 0.6159 \\
\hline $\mathrm{C} 24$ & $09^{\circ} 06.3866^{\prime} \mathrm{N}$ & $007^{\circ} 16.193^{\prime} \mathrm{E}$ & 0.230 & 230 & 0.2821 & 0.7870 \\
\hline $\mathrm{C} 25$ & $09^{\circ} 06.381^{\prime} \mathrm{N}$ & $007^{\circ} 16.180^{\prime} \mathrm{E}$ & 0.190 & 190 & 0.2330 & 0.6501 \\
\hline Mean \pm SD & & & $0.173 \pm 0.042$ & $173.2 \pm 41.7$ & $0.2124 \pm 0.0512$ & $0.5926 \pm 0.1427$ \\
\hline
\end{tabular}

Table 4: Summary of Exposure Dose Rate and Calculated Hazard Indices for the three Location

\begin{tabular}{|c|c|c|c|c|}
\hline Location & $\begin{array}{c}\text { Exposure } \\
\text { Rate } \\
(\mathbf{u S v} / \mathbf{h r})\end{array}$ & $\begin{array}{c}\text { Absorbed } \\
\text { Dose } \\
(\mathbf{n G} / \mathbf{h r})\end{array}$ & $\begin{array}{c}\text { AEDE } \\
(\text { Outdoor }) \\
(\mathbf{m S v} / \mathbf{y})\end{array}$ & $\begin{array}{c}\text { ELCR } \\
(\text { Outdoor }) \\
\mathbf{x} 10^{-3}\end{array}$ \\
\hline Site A & $0.177 \pm 0.046$ & $176.8 \pm 46.7$ & $0.2168 \pm 0.0572$ & $0.6049 \pm 0.1597$ \\
\hline Site B & $0.177 \pm 0.046$ & $176.8 \pm 46.7$ & $0.2168 \pm 0.0572$ & $0.6049 \pm 0.1597$ \\
\hline Site C & $0.173 \pm 0.042$ & $173.2 \pm 41.7$ & $0.2124 \pm 0.0512$ & $0.5926 \pm 0.1427$ \\
\hline Mean & $\mathbf{0 . 1 7 6} \pm \mathbf{0 . 0 4 5}$ & $\mathbf{1 7 5 . 6} \pm \mathbf{4 5 . 0 3}$ & $\mathbf{0 . 2 1 5 3} \pm \mathbf{0 . 0 5 5 2}$ & $\mathbf{0 . 6 0 0 8} \pm \mathbf{0 . 1 5 4 0}$ \\
\hline
\end{tabular}

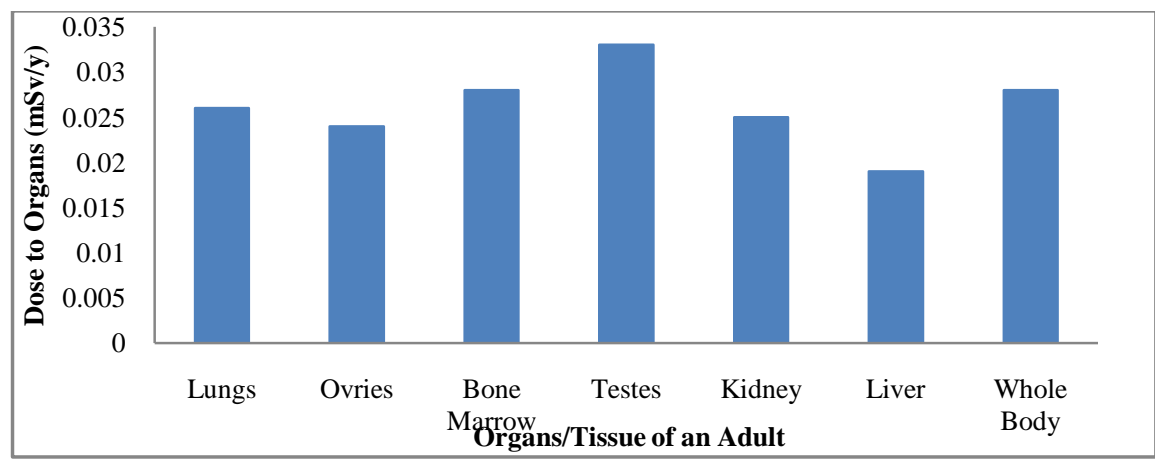

Figure 1: Effective Dose Rate to different Organs/Tissue 
Journal DOI: www.doi.org/10.46654/ij.24889849

Article DOI: www.doi.org/10.46654/ij.24889849.e7573

\section{CONCLUSION}

This study so far has assessed the radiological impact of activities in a major scrap metal market by the assessment of the outdoor radiation exposure levels and human health risk in the area.

From the study, the following conclusions are made:

1. The mean outdoor radiation exposure rate is $0.176 \pm 0.045 \mu \mathrm{Sv} / \mathrm{h}$, which is slightly higher than the standard background radiation of $0.133 \mu \mathrm{Sv} / \mathrm{h}$, but is below the ICRP maximum permissible limit of $0.57 \mu \mathrm{Sv} / \mathrm{h}$.

2. The AEDE ranges from $0.2124 \pm 0.0512 \mathrm{mSv} / \mathrm{y}$ to $0.2168 \pm 0.0572 \mathrm{mSv} / \mathrm{y}$ with a mean of $0.2153 \pm 0.0552 \mathrm{mSv} / \mathrm{y}$. These values are lower than the ICRP recommended limits of $1.0 \mathrm{mSv} / \mathrm{y}$ for the public and $20 \mathrm{mSv} / \mathrm{y}$ for occupationally exposed workers. However, periodic assessment of activity concentration of natural radionuclides and background radiation exposure levels in the study area should be carried out in order to ensure that exposure to radiation within the area is kept to as low as reasonably achievable.

3. The mean excess lifetime cancer risk values suggest that the probability of cancer development by workers and residents who wish to spend all their life time in the area is not probable.

4. The effective dose to organs are all below the international tolerable limits of $1.0 \mathrm{mSv} / \mathrm{y}$. These suggest that the impact of exposure to background ionizing radiation levels in the study area contributes insignificantly to the radiation dose to these organs of the adult.

4) Generally, The radiological assessment shows that the study area does not constitute any immediate radiological health effect on the workers and the general public due to radiation exposure rate. 


\section{References}

Agbalagba O. E (2017). Assessment of excess lifetime cancer risk from gamma radiation levels in Effurun and Warri city of Delta state, Nigeria. Journal of Taibah University for Science 11 (3):367-380.

Avwiri G. O; Nwaka B. U; Ononugbo C. P (2016). Radiological health risk due to gamma dose rates around OkposiOkwu and Uburu salt lakes, Ebonyi State. International Journal of Emerging Research in Management and Technology 5(9):36-46.

Avwiri G. O; Osimobi, J. C; Agbalagba E. O (2012), 'Evaluation of radiation hazard indices and excess lifetime cancer risk due to natural radioactivity in soil profile of Udi and Ezeagu local government areas of Enugu State, Nigeria', Comprehensive Journal of Environmental and Earth Sciences. 1. 1-10.

Benson, I. D; Ugbede, F. O (2018). Measurement of Background Ionizing Radiation And Evaluation Of Lifetime Cancer Risk In Highly Populated Motor Parks In Enugu City, Nigeria.” IOSR Journal of Applied Physics (IOSR-JAP), vol. 10, no. 3, pp. 77-82.

Etuk S. E; Essiett A. A; Okechukwu E; Agbasi O. E (2017) Measurement of Outdoor Ambient Radioactive Radiation and Evaluation of Radiation Indices and Excess Lifetime Cancer Risk within Uyo, Unity Park, Uyo, Nigeria JGEESI, 9(4): 1-9.

IAEA, (1996). International Basic Safety Standards for Protection against Ionizing Radiation and for the Safety of Radiation Sources, Safety Series No. 115, IAEA, Vienna.

ICRP, (1996). International Commission on Radiological Protection Age-dependent Doses to Members of the Public from Intake of Radionuclides. Part5: Compilation of Ingestion and Inhalation Coefficients. ICRP Publication 72, Pergamon Press, Oxford

ICRP, (2007). The Recommendations of the International Commission on Radiological Protection.

International Conference on Control and Management of Radioactive Material Inadvertently Incorporated into Scrap Metal, ICCMRM (2009). Organized by the Spanish Nuclear Safety Council in cooperation with the International Atomic Energy Agency, and held in the Tarragona, Spain. Pg 263-271. Proceedings series, ISSN 0074-1884.

Kerinja S. S; Ibrahim U; Yusuf S. D; Idris M. M; and Mundi A. A (2020). Assessment of Radiation Exposure Level from Some Scrap Metal Dumpsites in Nasarawa State, Nigeria. Asian Journal of Research and Reviews in Physics 3(2): 1-9, 2020.

Lenka M and Peter E (2010). End-of-waste criteria for iron and steel scrap: technical proposals. EUR-scientific and technical research

NCRP. (1976): Report No. 050 - Environmental Radiation Measurements. 
Journal DOI: www.doi.org/10.46654/ij.24889849

Article DOI: www.doi.org/10.46654/ij.24889849.e7573

Occupational Safety and Health Administration (OSHA) 2008. 'Guidance for the Identification and Control of Safety and Health Hazards in Metal Scrap Recycling' OSHA 3348-05.

Oyeyinka O. D., James I. U., Akueche E. C, Shonowo O. A., Adesanmi C. A. (2012). Estimation of Radiation Dose Rate Levels around a Nuclear Establishment in Abuja, North Central, Nigeria. Science and Technology 2(6): 163-167.

Qureshi A. A; Tariq S; Din K. U; Manzoor S; Calligaris C; Waheed A (2014) Evaluation of excessive lifetime cancer risk due to natural radioactivity in the rivers sediments of Northern Pakistan. Journal of Radiation Research and Applied Sciences, 7 (4): 438-447.

Taskin H; Karavus M; Ay P; Touzogh A; Hindiroglu S; Karaham G. (2009). Radionuclide concentration in soil and lifetime cancer risk due to the gamma radioactivity in Kirklareli, Turkey. Journal of Environmental Radioactivity. 100:49-50.

United Nations Economic Commission for Europe (UNECE) (2006). Recommendations on monitoring and response procedures for radioactive scrap metal. Report of An International Group of Experts Convened by the United Nations Economic Commission for Europe. UNITED NATIONS New York and Geneva.

Zaid Q. A; Khled. M. A; Anas M. A; Abdalmajeid M. A (2010). Measurement of Natural and Artificial radioactivity in Powder Milk corresponding Annual Effective Dose. Radiation Protection Dosimetry 138 (3): 278 - 283. 